\title{
Hubungan Frekuensi Kekambuhan Dermatitis Seboroik dengan Kualitas Hidup pada Pasien di Poliklinik Kulit dan Kelamin RSUP Dr. M. Djamil Padang
}

Ririn Lausarina ${ }^{1}$, Satya Wydya Yenny ${ }^{2}$, Ennesta Asri ${ }^{2}$

\begin{abstract}
Abstrak
Dermatitis seboroik merupakan kelainan kulit kronis papuloskuamosa yang sering terjadi pada kulit kepala, daerah folikel sebasea di wajah dan dada.Gambaran klinis yang tampak dari luar menimbulkan gangguan pada fisik, psikis, kehidupan sosial dan aktivitas sehari-hari pasien. Penyakit kulit ini mengharuskan pasien menanggung beban selama bertahun-tahun bahkan seumur hidupnya sehingga diduga dapat mempengaruhi kualitas hidupnya. Tujuan penelitian ini adalah menentukan hubungan frekuensi kekambuhan dermatitis seboroik dengan kualitas hidup pasien. Penelitian ini merupakan studi analitik dengan desain cross-sectional. Pengambilan sampel dilakukan dengan metode total sampling. Pengumpulan data dilakukan dengan pengambilan data sekunder melalui rekam medik pasien RSUP Dr. M. Djamil Padang dan menggunakan instrumen Dermatology Life Quality Index kepada 31 pasien yang menjadi sampel penelitian untuk penilaian kualitas hidup. Analisis data menggunakan analisis univariat dan bivariat dengan uji Kruskal-Wallis Test $(\alpha=0,05)$. Hasil penelitian menunjukkan 38,7\% pasien mengalami frekuensi kekambuhan dermatitis seboroik yang dikategorikan sering. Hampir setengah dari responden (41,9\%) merasakan dermatitis seboroik memberikan sedikit pengaruh terhadap kualitas hidupnya. Hasil penelitian memperlihatkan bahwa terdapat hubungan yang bermakna antara frekuensi kekambuhan dermatitis seboroik dengan kualitas hidup pada pasien di Poliklinik Kulit dan Kelamin RSUP Dr. M. Djamil Padang ( $p=0,031)$.
\end{abstract}

Kata kunci: dermatitis seboroik, kekambuhan, kualitas hidup

\begin{abstract}
Seborrheic dermatitis is a skin disorder with chronic papulosquamous, often occurs on the scalp, sebaceous follicle area of the face and chest. The clinical features that appear from the outside have physical impact, psychological, social life and daily activities of the patient. This skin disorder requires the patient to having impact of the disease for many years and even for a lifetime, so it will affect the quality of life. The objective of this study was to find the relationship between relapse frequency of seborrheic dermatitis and patient's quality of life. This is an analytic research with cross sectional method. Sampling techniques using total sampling. The data were collected by collecting the secondary data from patient's medical record in Dr. M. Djamil Hospital Padang and using the Dermatology Life Quality Index to 31 patients who become the research sample for quality of life assessment. Data were analyzed by using univariate and bivariate analyze with Kruskal-Wallis Test $(\alpha=0,05)$. The result of this research showed those $38,7 \%$ patients are grouped in the frequent relaps. Almost half of the respondents (41.9\%) felt a little affect the quality of life. The result of this research showed that there is a significant correlation of relapse frequency of seborrheic dermatitis and quality of life on patients in Dermatovenerology Polyclinic of Dr. M. Djamil Hospital Padang $(p=0.031)$.
\end{abstract} Keywords: seborrheic dermatitis, relapse, quality of life

Affiliasi penulis: 1. Prodi Kedokteran Fakultas Kedokteran Universitas Andalas Padang (FK Unand), 2. Bagian Kulit dan Kelamin FK Unand/RSUP Dr. M. Djamil Padang,
Korespondensi: Ririn Lausarina, email: lausarinaririn@gmail.com Telp: 081261989159 


\section{PENDAHULUAN}

Dermatitis seboroik adalah suatu kelainan kulit kronis papuloskuamosa yang sering ditemukan dan mudah dikenali. Kelainan kulit ini dapat terjadi pada bayi dan dewasa. Dermatitis seboroik sering dikaitkan dengan malassezia, dimana terjadi gangguan imunologis mengikuti kelembaban lingkungan, perubahan cuaca ataupun trauma. Predileksi dermatitis seboroik pada kulit kepala dan daerah folikel sebasea di wajah (terutama lipatan nasolabial) dan dada. Kulit tampak berwarna merah muda ditutupi sisik kuning kecoklatan dan krusta. Penyebaran lesi dimulai dari derajat ringan sampai derajat berat, seperti ketombe sampai dengan eritroderma. ${ }^{1}$

Prevalensi dermatitis seboroik pada populasi umum sebesar $1 \%$ - 3\% dan $34 \%$ - $83 \%$ pada orang dengan defisiensi imun. Penelitian di Amerika menunjukkan 3\% - 5\% dermatitis seboroik terjadi pada dewasa. Dermatitis seboroik lebih sering terjadi pada laki-laki daripada perempuan pada semua kelompok umur. ${ }^{1}$

Data di Rumah Sakit Umum Pusat Nasional Dr. Cipto Mangunkusumo pada tahun 2000-2002 tercatat insidensi dermatitis seboroik sebesar $8,3 \%$ dari total kunjungan pasien. $^{2}$ Di Poliklinik Kulit dan Kelamin RSUP Dr M Djamil Padang dilaporkan sebanyak 73 kunjungan pasien dengan dermatitis soboroik pada tahun 2016, dimana insiden dermatitis seboroik ini mengalami peningkatan dari tahun sebelumnya. ${ }^{3}$

Dermatitis seboroik disebabkan oleh banyak faktor. Ada 3 faktor yang diduga sebagai penyebab utama terjadinya dermatitis seboroik yaitu produksi sebum berlebihan yang merupakan sekresi glandula sebasea, metabolisme mikroba yaitu Malassezia dan kerentanan individu. Pada kelompok imunokompromais akan mengalami peningkatan insidensi dermatitis seboroik. ${ }^{4}$

Menurut penelitian yang dilakukan di Manado, wajah merupakan lokasi terbanyak sebagai tempat munculnya lesi dermatitis seboroik. ${ }^{5}$ Gejala yang muncul pada penderita dermatitis seboroik ini berupa skuama kuning berminyak dan krusta di atas kulit eritema ringan sampai dengan plak yang sangat merah. ${ }^{6}$ Pada bentuk yang lebih berat, terdapat lesi pada kepala yang ditutupi oleh krusta kotor dan berbau tidak sedap. Sebagian besar penderita dermatitis seboroik mengeluhkan rasa gatal dan sensasi menyengat, dimana sebagian lainnya asimtomatik. ${ }^{7}$ Berdasarkan predileksi, gambaran lesi yang muncul dan keluhan yang dirasakan dapat memberikan pengaruh yang besar terhadap kepercayaan diri penderita dermatitis seboroik. $^{5}$

Gambaran klinis yang tampak dari luar dapat memberikan dampak psikososial yang signifikan. Rasa cemas, depresi, marah, malu dan tidak percaya diri dapat membuat pasien mengisolasi diri dari masyarakat. Gangguan fisik, psikis, kehidupan sosial dan aktivitas sehari-hari pasien akan memberikan efek negatif terhadap kualitas hidup pasien. ${ }^{8}$

Dermatitis seboroik merupakan inflamasi kronik pada kulit yang dapat bertahan selama bertahun-tahun melalui kekambuhan dan remisi. ${ }^{9}$ Penelitian di Thailand melaporkan sebesar $68,1 \%$ pasien dengan kekambuhan kronis dan kadang-kadang mengalami eksaserbasi. Sejumlah 20,5\% pasien mengalami gejala yang menetap dan berkelanjutan. Frekuensi kekambuhan dermatitis seboroik dapat terjadi dalam rentang waktu sekali dalam 4 tahun sampai setiap minggu. Angka median kekambuhan tersebut yaitu 6 kali dalam setahun. ${ }^{7}$

Dermatitis seboroik tergolong penyakit kulit kronik, mengharuskan pasien menanggung beban penyakit selama bertahun-tahun bahkan seumur hidup. Lamanya penderitaan yang ditanggung oleh pasien membuat penilaian pengaruh penyakit kulit tersebut terhadap kualitas hidup menjadi suatu hal yang penting dalam tata laksana dan perbaikan kualitas hidup merupakan tujuan terapi yang utama. ${ }^{8}$

Menurut World Health Organization (WHO), kualitas hidup adalah persepsi seseorang dalam konteks budaya dan norma yang sesuai dengan tempat hidupnya serta terkait dengan tujuan, harapan, standar dan kepedulian selama hidupnya. ${ }^{10}$

Rata-rata pasien dermatitis seboroik mengalami gangguan kualitas hidup ringan. ${ }^{11}$ Berbeda dengan hasil penelitian yang dilakukan di Afrika Selatan, pasien merasakan pengaruh yang sangat besar terhadap kehidupannya. ${ }^{12}$

Penilaian kualitas hidup pasien dermatitis seboroik dapat dinilai berdasarkan faktor-faktor yang mempengaruhinya seperti, jenis kelamin penderita, tingkat pendidikan, lokasi lesi dan derajat 


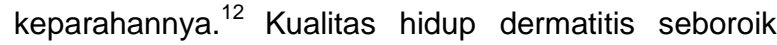
juga dapat dipengaruhi oleh kekambuhan yang dialami oleh penderita karena bersifat kronik residif. ${ }^{7}$ Belum ada data penelitian yang menghubungkan secara langsung tingkat kekambuhan dermatitis seboroik dengan kualitas hidup penderita dermatitis seboroik.

Berdasarkan uraian di atas dan terkait bahwa penelitian mengenai hal tersebut belum pernah dilakukan pada pasien di RSUP Dr. M. Djamil Padang, maka peneliti berminat untuk menggali hubungan frekuensi kekambuhan dermatitis seboroik dengan kualitas hidup pada pasien di Poliklinik Kulit dan Kelamin RSUP Dr. M. Djamil Padang.

\section{METODE}

Jenis penelitian ini adalah analitik dengan desain cross sectional. Penelitian ini menggunakan data rekam medis sebagai data awal untuk survei terhadap pasien dengan diagnosis dermatitis seboroik. Penelitian dilaksanakan di Poliklinik Kulit dan Kelamin RSUP Dr M Djamil Padang, Instalasi Rekam Medis RSUP Dr M Djamil Padang dan rumah pasien. Penelitian dilaksanakan pada bulan Februari sampai Juni 2018.

Populasi dalam penelitian ini adalah semua pasien dengan diagnosis dermatitis seboroik di Poliklinik Kulit dan Kelamin RSUP DR. M. Djamil Padang pada tahun 2015-2017.

Sampel penelitian yang dipilih adalah semua populasi yang memenuhi kriteria inklusi dan tidak memiliki kriteria eksklusi. Kriteria inklusi subjek: Pasien usia > 18 tahun dengan diagnosis dermatitis seboroik di Poliklinik Kulit dan Kelamin RSUP Dr. M. Djamil Padang; pasien bersedia menjadi reponden dalam penelitian ini. Kriteria eksklusi subjek: Pasien yang tidak memberikan alamat rumah atau nomor telepon yang bisa dihubungi pada data rekam medis di RSUP Dr. M. Djamil Padang; pasien yang baru pertama kali merasakan gejala dermatitis seboroik saat datang ke Poliklinik Kulit dan Kelamin RSUP Dr. M. Djamil Padang; pasien dengan keadaan lain seperti HIV dan AIDS; pasien yang tidak berdomisili di Kota Padang. Teknik pengambilan sampel dengan metode total sampling.
Data diperoleh dengan cara melihat catatan rekam medis dan menghubungi serta mengunjungi rumah pasien untuk pengisian kuesioner. Kuesioner yang digunakan adalah Dermatology Life Quality Index (DLQI) untuk menentukan kualitas hidup.

Data dianalisis secara statistik berdasarkan variabel yang dinilai menggunakan sistem komputerisasi yaitu analisis univariat dan bivariat. Analisis univariat dilakukan untuk melihat distribusi dan frekuensi dari masing-masing variabel independen dan variabel dependen yaitu kekambuhan dermatitis seboroik dan kualitas hidup pasien. Analisis bivariat dilakukan untuk menganalisis hubungan antara variabel independen dan variabel dependen. Hubungan dua variabel tersebut dianalisis dengan menggunakan uji Kruskal-Wallis Test dan dikatakan bermakna bila $p \leq 0.05$.

\section{HASIL}

Penelitian telah dilaksanakan pada pasien dermatitis seboroik di Poliklinik Kulit dan Kelamin RSUP Dr. M. Djamil Padang periode 2015 - 2017. Penelitian dilakukan dengan melihat data sekunder di rekam medis dan mendatangi rumah pasien satu per satu.Penelitian dilakukan dengan 31 orang sampel yang memenuhi kriteria inklusi dan eksklusi.

\section{Karakteristik Responden}

Tabel 1. Distribusi dermatitis seboroik berdasarkan usia di poliklinik kulit dan kelamin RSUP Dr M Djamil Padang

\begin{tabular}{rcc}
\hline Usia & $\mathbf{f}$ & $\%$ \\
\hline 18-27 tahun & 1 & 3,2 \\
28-37 tahun & 0 & 0,0 \\
38-47 tahun & 2 & 6,5 \\
48-57 tahun & 3 & 9,7 \\
58-67 tahun & 5 & 16,1 \\
$68-77$ tahun & 14 & 45,2 \\
78-87 tahun & 6 & 19,4 \\
\hline Total & 31 & 100,0 \\
\hline
\end{tabular}

Berdasarkan Tabel 1 didapatkan bahwa distribusi dermatitis seboroik di Poliklinik Kulit dan Kelamin RSUP Dr. M. Djamil Padang terbanyak pada usia 68-77 tahun yaitu sebanyak 14 orang $(45,2 \%)$. 
Tabel 2. Distribusi dermatitis seboroik berdasarkan jenis kelamin di poliklinik kulit dan kelamin RSUP Dr M Djamil Padang

\begin{tabular}{lcc}
\hline \multicolumn{1}{c}{ Jenis Kelamin } & $\mathbf{f}$ & $\%$ \\
\hline Laki-laki & 18 & 58,1 \\
Perempuan & 13 & 41,9 \\
\hline Total & 31 & 100,0 \\
\hline
\end{tabular}

Pada Tabel 2 dapat disimpulkan bahwa distribusi dermatitis seboroik di Poliklinik Kulit dan Kelamin RSUP Dr. M. Djamil Padang paling banyak pada laki-laki yaitu sebanyak 18 orang $(58,1 \%)$.

Tabel 3. Distribusi dermatitis seboroik berdasarkan lokasi lesi di poliklinik kulit dan kelamin RSUP Dr M Djamil Padang

\begin{tabular}{lcc}
\hline \multicolumn{1}{c}{ Lokasi Lesi } & $\mathbf{f}$ & $\%$ \\
\hline Kulit kepala & 14 & 45,2 \\
Wajah & 5 & 16,1 \\
Badan & 5 & 16,1 \\
Tangan & 2 & 6,5 \\
Kaki & 5 & 16,1 \\
\hline Total & 31 & 100,0 \\
\hline
\end{tabular}

Berdasarkan Tabel 3 memperlihatkan kulit kepala merupakan lokasi lesi terbanyak dermatitis seboroik pada pasien di Poliklinik Kulit dan Kelamin RSUP Dr. M. Djamil Padang. Sejumlah 14 orang $(45,2 \%)$ mengalami dermatitis seboroik di kulit kepala.

\section{Gambaran Kekambuhan Dermatitis Seboroik}

Tabel 4. Distribusi frekuensi kekambuhan dermatitis seboroik di poliklinik kulit dan kelamin RSUP Dr M Djamil Padang

\begin{tabular}{lcc}
\hline \multicolumn{1}{c}{ Frekuensi Kekambuhan } & $\mathbf{f}$ & $\%$ \\
\hline Jarang & 11 & 35,5 \\
Kadang-kadang & 8 & 25,8 \\
Sering & 12 & 38,7 \\
\hline Total & 31 & 100,0 \\
\hline
\end{tabular}

Berdasarkan Tabel 4 didapatkan bahwa sampel dalam penelitian ini sering mengalami kekambuhan dermatitis seboroik. Sejumlah 12 orang sampel $(38,7 \%)$ mengalami kekambuhan yang dikategorikan sering.

\section{Kualitas Hidup pada Pasien Dermatitis Seboroik}

Berdasarkan penelitian yang telah dilaksanakan, didapatkan informasi mengenai kualitas hidup pada pasien dermatitis seboroik sebagai berikut :

Tabel 5. Distribusi kualitas hidup pasien dermatitis seboroik di poliklinik kulit dan kelamin RSUP Dr. M. Djamil Padang

\begin{tabular}{lcc}
\hline \multicolumn{1}{c}{ Kualitas Hidup } & $\mathbf{f}$ & $\%$ \\
\hline Tidak berpengaruh & 2 & 6,5 \\
Sedikit berpengaruh & 13 & 41,9 \\
Berpengaruh sedang & 8 & 25,8 \\
Sangat berpengaruh & 6 & 19,4 \\
Amat sangat berpengaruh & 2 & 6,5 \\
\hline Total & 31 & 100,0 \\
\hline
\end{tabular}

Penilaian kualitas hidup pasien dermatitis seboroik di Poliklinik Kulit dan Kelamin RSUP Dr.M.Djamil Padang berdasarkan tabel 5.5 didapatkan hampir semua pasien merasakan dermatitis seboroik mempengaruhi kualitas hidupnya. Paling banyak pasien merasakan bahwa dermatitis seboroik sedikit mempengaruhi kualitas hidupnya yaitu sejumlah 13 orang $(41,9 \%)$.

Hubungan Frekuensi Kekambuhan Dermatitis Seboroik dengan Kualitas Hidup Pasien

Berdasarkan penelitian yang telah dilakukan, didapatkan data sebagai berikut : 
Tabel 6. Hubungan frekuensi kekambuhan dermatitis seboroik dengan kualitas hidup pasien di poliklinik kulit dan kelamin RSUP Dr. M. Djamil Padang

\begin{tabular}{|c|c|c|c|c|c|c|c|c|c|c|c|c|c|}
\hline \multirow{3}{*}{$\begin{array}{c}\text { Frek. } \\
\text { DS }\end{array}$} & \multicolumn{10}{|c|}{ Kualitas Hidup } & & & \\
\hline & \multicolumn{2}{|c|}{ TB } & \multicolumn{2}{|c|}{ Se B } & \multicolumn{2}{|c|}{ BS } & \multicolumn{2}{|c|}{ Sa B } & \multicolumn{2}{|c|}{ ASB } & \multicolumn{2}{|c|}{ Total } & \multirow[t]{2}{*}{ p } \\
\hline & $f$ & $\%$ & $f$ & $\%$ & $\mathbf{f}$ & $\%$ & $\mathbf{f}$ & $\%$ & $f$ & $\%$ & f & $\%$ & \\
\hline Jrg & 0 & 0,0 & 9 & 81,8 & 2 & 18,2 & 0 & 0,0 & 0 & 0,0 & 11 & 100 & \\
\hline Kdg & 1 & 12,5 & 2 & 25,0 & 3 & 37,5 & 2 & 25,0 & 0 & 0,0 & 8 & 100 & 0,031 \\
\hline Srg & 1 & 8,3 & 2 & 16,7 & 3 & 25,0 & 4 & 33,3 & 2 & 16,7 & 12 & 100 & \\
\hline Total & 2 & 6,5 & 13 & 41,9 & 8 & 25,8 & 6 & 19,4 & 2 & 6,5 & 31 & 100 & \\
\hline
\end{tabular}

Keterangan:

Jrg=Jarang, Kdg=Kadang-kadang, Srg=Sering, TB=Tidak Berpengaruh, SeB=Sedikit Berpengaruh, BS=Berpengaruh Sedang,

$\mathrm{SaB}=$ Sangat Berpengaruh, $\mathrm{ASB}=$ Amat Sangat Berpengaruh

Hubungan antara frekuensi kekambuhan dermatitis seboroik dengan kualitas hidup pasien didapatkan melalui analisis menggunakan komputerisasi SPSS dengan teknik analisis KruskalWallis Test dengan taraf signifikasi $(\alpha)<0.05$.

Berdasarkan Tabel 6 didapatkan bahwa pada frekuensi kekambuhan dermatitis seboroik yang jarang paling banyak memberikan sedikit pengaruh dalam kualitas kehidupan yaitu sebanyak 9 orang $(81,8 \%)$. Kemudian, kekambuhan dermatitis seboroik yang dikategorikan kadang-kadang, paling banyak memberikan pengaruh sedang terhadap kehidupan yaitu sejumlah 3 orang (37,5\%). Frekuensi kekambuhan dermatitis seboroik yang sering, didapatkan paling banyak sampel merasakan sangat berpengaruh terhadap kehidupannya yaitu sebanyak 4 orang $(33,3 \%)$.

Tabel di atas juga memperlihatkan bahwa sampel dalam penelitian ini paling banyak mengalami dermatitis seboroik dengan frekuensi kekambuhan yang sering dan dapat memberikan sedikit pengaruh dalam kehidupannya.Kesimpulan yang dapat ditarik dari tabel di atas adalah adanya hubungan yang bermakna antara frekuensi kekambuhan dengan kualitas hidup pasien di Poliklinik Kulit dan Kelamin RSUP Dr. M. Djamil Padang. Hal ini dikarenakan nilai $p$-value yang didapatkan setelah dilakukan uji analasis Kruskal-Wallis Test adalah $\leq 0,05$ yaitu 0,031 .

\section{PEMBAHASAN}

\section{Karakteristik Responden}

Distribusi dermatitis seboroik berdasarkan usia pasien di Poliklinik Kulit dan Kelamin RSUP Dr. M. Djamil Padang berdasarkan penelitian ini, didapatkan rentang usia 68 - 77 tahun merupakan usia terbanyak yang mengalami dermatitis seboroik yaitu sejumlah 14 orang $(45,2 \%)$. Hasil penelitian ini didukung oleh yang dilakukan di RSUD Abdul Moeloek Provinsi Lampung pada tahun 2013, dimana angka kejadian dermatitis seboroik tertinggi berada pada kelompok usia $63-72$ tahun yaitu sebesar $31,3 \%$. $^{13}$

Dermatitis seboroik mengalami peningkatan insidensi seiring dengan pertambahan usia karena terjadi beberapa perubahan fisiopatologis. Salah satunya akan terjadi penurunan jumlah lipid di stratum korneum dan penipisan epidermis serta dermis. Hal ini dapat mengakibatkan kerentanan yang lebih tinggi terhadap rangsangan eksternal pada kelompok usia lanjut. ${ }^{14}$ Daya tahan tubuh yang semakin menurun dapat mengakibatkan orang dengan lanjut usia menjadi rentan terhadap berbagai macam penyakit, seperti dermatitis seboroik. ${ }^{15}$

Distribusi dermatitis seboroik berdasarkan jenis kelamin di Poliklinik Kulit dan Kelamin RSUP Dr. M. Djamil Padang paling banyak adalah laki-laki, yaitu sejumlah 18 orang $(58,1 \%)$. Hasil ini didukung oleh penelitian The Rotterdam Study yang menunjukkan 
bahwa proporsi kejadian dermatitis seboroik pada lakilaki dibandingkan perempuan adalah $1,4: 1{ }^{14}$

Jenis kelamin merupakan salah satu faktor risiko terjadinya dermatitis seboroik.Laki-laki mengalami peningkatan insiden dua kali lebih besar dibandingkan perempuan, dikaitkan dengan stimulasi hormon androgen. Produksi hormon androgen lebih tinggi pada laki-laki, sehingga produksi sebum lebih banyak pada laki-laki akibat dari peningkatan aktivitas kelenjar sebasea. ${ }^{14,15}$ Peningkatan sebum dapat menginduksi proliferasi Malassezia dan memicu terjadinya dermatitis seboroik. ${ }^{14}$

Responden laki-laki dalam penelitian ini juga banyak yang berasal dari kelompok usia lanjut. Kejadian dermatitis seboroik juga dapat dihubungkan dengan terjadinya kehilangan rambut karena proses penuaan. ${ }^{16}$ Rambut berfungsi sebagai proteksi terhadap lingkungan yang merugikan seperti suhu dingin atau panas, dan sinar ultraviolet. ${ }^{17}$ Sesuai dengan kepustakaan yang menyatakan bahwa peningkatan insidensi dermatitis seboroik berhubungan dengan faktor iklim yang panas dan paparan radiasi ultraviolet, maka peningkatan insidensi dapat disebabkan karena terjadinya penipisan rambut dan laki-laki yang lebih sering berkegiatan di luar rumah sehingga terpapar sinar matahari secara langsung dengan frekuensi lebih tinggi dibandingkan perempuan. $^{7}$

Berdasarkan penelitian yang telah dilakukan, lokasi lesi dermatitis seboroik paling banyak terjadi pada kulit kepala yaitu 45,2\%. Hasil penelitian ini didukung oleh penelitian di Turki yang menunjukkan bahwa $94,1 \%$ dermatitis seboroik terjadi pada kulit kepala. ${ }^{18} \mathrm{Hal}$ ini berhubungan dengan jumlah produksi sebum yang menjadi salah satu faktor terjadinya dermatitis seboroik. Peningkatan produksi sebum terjadi pada daerah-daerah dengan kelenjar sebasea yang banyak diantaranya adalah kulit kepala, wajah dan leher. ${ }^{1} \quad$ Sesuai dengan kepustakaan yang menyatakan bahwa paparan sinar matahari juga dapat berperan sebagai faktor pencetus terjadinya dermatitis seboroik, maka daerah-daerah terbuka seperti kulit kepala, wajah dan leher lebih sering menjadi lokasi lesi dermatitis seboroik. $^{7}$

\section{Gambaran Kekambuhan Dermatitis Seboroik}

Penelitian ini mendapatkan bahwa pasien paling banyak mengalami dermatitis seboroik dengan frekuensi kekambuhan yang sering yaitu sebanyak $38,7 \%$ dari total 31 orang pasien. Penelitian ini sesuai dengan studi Hidayani yang dilakukan pada tahun 2016, didapatkan pasien paling banyak mengalami kekambuhan dermatitis seboroik yang sering yaitu sebanyak $59,4 \%{ }^{19}$

Hal ini sesuai dengan kepustakaan yang mengatakan bahwa dermatitis seboroik merupakan dermatitis yang sering kambuh, ditandai dengan bercak eritematosa dengan lesi superfisial. ${ }^{11}$ Penelitian Dessinioti dan Katsambas yang dilakukan pada tahun 2013 juga menyebutkan bahwa dermatitis seboroik merupakan penyakit kulit yang bersifat kronik residif, penyakit ini dapat menetap selama bertahun-tahun dan mudah kambuh. ${ }^{20}$

Kekambuhan dermatitis seboroik yang sering terjadi disebabkan oleh banyaknya faktor pemicu kekambuhan tersebut. Stress emosional, depresi, kelelahan, paparan berlebihan terhadap pendingin ruangan dan cuaca yang panas dapat memicu kekambuhan dermatitis seboroik.Infeksi sistemik dan penggunaan obat-obatan menjadi penyebab kekambuhan tersering pada pasien dengan usia lanjut. $^{21}$ Faktor predisposisi genetik juga berperan dalam timbulnya dermatitis seboroik. ${ }^{19}$

\section{Kualitas Hidup pada Pasien Dermatitis Seboroik}

Berdasarkan penelitian ini, didapatkan hampir semua pasien dermatitis seboroik merasakan bahwa dermatitis seboroik mempengaruhi kualitas hidupnya. Terdapat $41,9 \%$ pasien merasakan bahwa dermatitis seboroik sedikit mempengaruhi kehidupannya. Hal ini sesuai dengan kepustakaan yang menyatakan bahwa sebagaimana penyakit dermatosis inflamasi lainnya, dermatitis seboroik juga dilaporkan berhubungan dengan penurunan kualitas hidup. ${ }^{11}$

Dermatitis seboroik dapat mempengaruhi psikologi dan kualitas kehidupan orang-orang yang menderita dermatitis seboroik dengan kekambuhan kronis. Penyakit kulit kronis memiliki dampak fisik dan emosional pada kualitas hidup seseorang, meliputi 
rasa tidak nyaman, stigmatisasi, kehilangan rasa percaya diri dan keterbatasan dalam aktivitas sosial. ${ }^{7}$

Rasa gatal dan rasa tidak nyaman merupakan hal yang sangat mengganggu bagi pasien dan seringkali ini merupakan alasan utama yang menyebabkan pasien datang untuk berobat. Gambaran klinis yang tampak dari luar juga dapat memberikan efek psikososial yang signifikan. Gangguan fisik, psikis, kehidupan sosial dan aktivitas sehari-hari dapat mempengaruhi kualitas hidup pasien. $^{8}$

\section{Hubungan Frekuensi Kekambuhan Dermatitis Seboroik dengan Kualitas Hidup Pasien}

Penelitian ini mendapatkan bahwa terdapat hubungan yang bermakna antara frekuensi kekambuhan dermatitis seboroik dengan kualitas hidup pada pasien di Poliklinik Kulit dan Kelamin RSUP Dr. M. Djamil Padang. Hal ini sesuai dengan penelitian yang dilakukan di Thailand yang menunjukkan bahwa rata-rata pasien mengalami kekambuhan sebanyak 8 kali setiap tahunnya dan terdapat sebanyak 3,6\% dari jumlah responden yang merasakan pengaruh amat sangat besar terhadap kehidupannya. ${ }^{7}$

Dermatitis seboroik merupakan penyakit kulit yang bersifat kronik residif. Penyakit tersebut dapat bertahan selama bertahun-tahun dan mudah

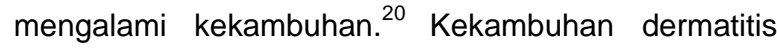
seboroik dapat terjadi dengan mudah karena banyak faktor yang dapat memicunya antara lain stress emosional, depresi, kelelahan, paparan berlebihan terhadap pendingin ruangan ataupun kondisi yang terlalu panas, infeksi sistemik dan penggunaan obatobatan tertentu. ${ }^{21}$

Dermatitis seboroik mengalami insiden puncak pada dekade keempat sampai ketujuh kehidupan sehingga pasien dermatitis seboroik didominasi oleh lanjut usia. Kualitas hidup semakin menurun dengan meningkatnya umur karena risiko menderita penyakit dan timbulnya stress semakin besar. Menurunnya kondisi kesehatan dapat mengakibatkan keterbatasan aktivitas sehingga menimbulkan keluhan kualitas hidup yang menurun. ${ }^{22}$

Hal ini didukung oleh penelitian sebelumnya yang menunjukkan bahwa sebanyak $76,4 \%$ responden dalam penelitian tersebut mengalami kekambuhan dikarenakan stress atau depresi, sebanyak 44,3\% mengalami kekambuhan karena perubahan cuaca, pengaruh paparan pendingin ruangan sebanyak $17,7 \%$ dan terpapar sinar matahari sebanyak 13,7\%. Faktor pencetus kekambuhan yang paling sering terjadi pada usia > 60 tahun adalah penyakit infeksi dan penggunaan obat-obatan $(12,5 \%$ dan $7,1 \%) .{ }^{23}$

Kekambuhan dermatitis seboroik dapat mempengaruhi kualitas hidup pasien. Kekambuhan tersebut ditandai adanya periode eksaserbasi dengan interval yang bervariasi. ${ }^{21}$ Kekambuhan yang sering terjadi membuat pasien merasakan gejala dermatitis seboroik dan dampak yang ditimbulkan secara berulang sehingga dapat menurunkan kualitas hidup pasien tersebut. $^{8}$

Penurunan kualitas hidup dapat terjadi karena pasien seringkali mengalami gejala dermatitis seboroik di lokasi yang tampak dari luar sehingga dapat memberikan efek negatif terhadap kehidupannya. ${ }^{24}$ Penelitian yang dilakukan di RSUD Abdul Moeloek Provinsi Lampung menunjukkan wajah merupakan lokasi lesi dermatitis seboroik tersering yaitu sebanyak $32,5 \% .{ }^{13} \mathrm{Hal}$ tersebut juga mendukung penelitian yang dilakukan saat ini, wajah merupakan lokasi lesi terbanyak setelah kulit kepala. Gambaran klinis yang tampak dari luar dapat memicu munculnya perasaan cemas, depresi, marah, malu dan tidak percaya diri sehingga membuat pasien mengisolasi diri dari masyarakat. Hal tersebut memberikan dampak

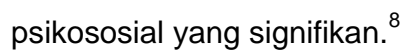

Rasa gatal dan rasa tidak nyaman yang dirasakan merupakan hal yang sangat mengganggu bagi pasien dan seringkali ini merupakan alasan utama yang menyebabkan pasien datang untuk berobat. ${ }^{8}$ Dalam penelitian ini, kulit kepala merupakan lokasi lesi tersering yaitu sebanyak 45,2\%. Hasil penelitian ini sesuai dengan yang dilakukan Bas et al di Turki, penelitian tersebut menunjukkan hampir semua pasien mengalami dermatitis seboroik pada kulit kepala yaitu sebanyak $94,1 \%{ }^{18}$

Dermatitis seboroik pada kulit kepala mengakibatkan kulit kepala tampak berminyak, nyeri, gatal, kemerahan dan gejala lainnya. Hal ini dapat menimbulkan pandangan yang buruk dari orang lain terhadap penyakit kulit yang diderita baik secara langsung maupun tidak langsung sehingga 
memberikan dampak negatif terhadap aktivitas sosial penderita. Pasien dermatitis seboroik dalam menghadapi situasi tersebut juga dapat meningkatkan depresi pada dirinya sehingga memperberat gejala dan semakin mempengaruhi kualitas hidup pasien tersebut. $^{8}$

Gangguan fisik, psikis, kehidupan sosial dan aktivitas sehari-hari pasien akan memberikan efek negatif terhadap kualitas hidup pasien meskipun dermatitis seboroik bukanlah penyakit yang mengancam nyawa. ${ }^{1}$ Gejala klinis dan efek yang ditimbulkan tidak hanya sekali dirasakan oleh pasien penyakit kronis seperti halnya dermatitis seboroik ini. Dermatitis seboroik yang kronis dan mudah kambuh mengharuskan pasien menanggung beban penyakit tersebut selama bertahun-tahun bahkan seumur hidupnya. $^{8}$ Sehingga dalam penelitian ini dapat disimpulkan bahwa semakin sering frekuensi kekambuhan dermatitis seboroik, maka semakin menurun kualitas hidup yang dirasakan oleh pasien dermatitis seboroik.

\section{SIMPULAN}

Hampir semua responden merasakan dermatitis seboroik memberikan pengaruh terhadap kualitas hidupnya, dengan kategori tertinggi adalah sedikit mempengaruhi kualitas hidup pasien.

Terdapat hubungan yang bermakna antara frekuensi kekambuhan dermatitis seboroik dengan kualitas hidup pada pasien di Poliklinik Kulit dan Kelamin RSUP Dr. M. Djamil Padang.

\section{DAFTAR PUSTAKA}

1. Plewig G, Jansen T. Seborrheic Dermatitis. Dalam: Wolff K, Goldsmith LA, Katz SI, Gilchrest BA, Paller AS, Leffell DJ, editor (penyunting). Fitzpatrick's dermatology in general medicine. Edisi ke-7. New York: McGraw Hill; 2008.hlm.219-25.

2. Kurniati D. Dermatitis Seboroik. Dalam: Tjarta A, Sularsito SA, Rihatmaja R, editor (penyunting). Metode diagnostik dan penatalaksanaan psoriasis dan dermatitis seboroik. Jakarta: Fakultas Kedokteran Universitas Indonesia; 2003. p. 53-61.

3. Bagian Rekam Medik RSUP Dr. M. Djamil Padang. Rekam medik Januari 2014-September 2017.
4. Borda LJ, Wikramanayake TC. Seborrheic dermatitis and dandruff: a comprehensive review. J Clin Investig Dermatol. 2015; 3(2):1-22.

5. Terroe RO, Kapantow MG, Kandou RT. Profil dermatitis seboroik di poliklinik kulit dan kelamin RSUP Prof DR RD Kandou Manado periode Januari-Desember 2012. Jurnal e-Clinic (eCl). 2015; 3(1):237-42.

6. Gayatri L, Barakbah J. Dermatitis seboroik pada HIV/AIDS. Berkala IImu Kesehatan Kulit \& Kelamin. 2011;23(3): 229-33.

7. Araya M, Kulthanan K, Jiamton S. Clinical characteristics and quality of life of seborrheic dermatitis patients in a tropical country. Indian Journal of Dermatology. 2015; 60(5): 519.

8. Rahmatina. Uji validitas dan realiabilitas dermatology life quality index (DLQI) berbahasa Indonesia pada pasien poliklinik ilmu kesehatan kulit dan kelamin rumah sakit DR. Cipto Mangunkusumo (tesis). Jakarta: Fakultas Kedokteran Universitas Indonesia; 2013.

9. Imamoglu B, Hayta SB, Guner R, Akyol M, Ozcelik S. Metabolic syndrome may be an important comorbidity in patients with seborrheic dermatitis. Arch Med Sci Atheroscler. 2016;1: e158-e61.

10. Vahedi S. World health organization quality-of-life scale (WHOOQOL-BREF): Analyses of their item response theory properties based on the graded responses model. Iranian J Psychiatry. 2010;5(4): 140-53.

11. Wakelin S. Seborrheic dermatitis. Dalam:Griffths C, Barker J, Chalmers R, Creamer D, editors. Rook's Textbook of Dermatology. Edisi ke-9. New York: John Wiley \& Sons; 2016.hlm. 40.1-40.6.

12. Moodley N, Hoosen K, Dlova NC. Quality of life in patients with seborrheic dermatitis in KwaZuluNatal, South Africa. S Afr Med J. 2016;106(5): 428.

13. MN Fadila, HT Sibero, A Wahyuni, MS Hamzah. Correlation between dermatitis seborrhea with quality of life in patients at Abdul Moeloek Hospital Lampung. Medical Journal of Lampung University. 2014; 3(6):118-25.

14. Sanders MGH, Pardo LM, Franco OH, Ginger RS, Nijsten T. Prevalence and determinants of seborrheic dermatitis in a middle aged and elderly 
population: the Rotterdam study. $\mathrm{Br} \mathrm{J}$ Dermatol. 2017. 178:148-53.

15. Malak S, Kandou RT, Pandaleke TA. Profil dermatitis seboroik di poliklinik kulit dan kelamin RSUP Prof Dr RD Kandou Manado periode Januari-Desember 2015. Jurnal e-Clinic (eCl). 2016;4(1):201-6.

16. Hordinsky M, Sawaya M, Roberts JL. Hair loss and hirsutism in the elderly. Geriatric Dermatology, Part II. 2002;18(1):121-32.

17. Purnamasari D, Suhartiningsih. Pengaruh jumlah air bonggol pisang klutuk terhadap sifat fisik dan masa simpan hair tonic rambut rontok. Jurnal Tata Rias. 2013;2(3): 61-9.

18. Bas Y, Seckin HY, Kalkan G, Takci Z, Citil R, Onder $Y$, et al. Prevalence and related factors of psoriasis and seborrheic dermatitis: a community based study. Turk J Med Sci. 2016;46:303-9.

19. Hidayani RD. Hubungan tingkat stres psikososial dengan kekambuhan dermatitis seboroik pada pasien di Poliklinik Kulit dan Kelamin RSUP DR. M. Djamil Padang (skripsi). Padang: Fakultas Kedokteran Universitas Andalas; 2016.
20. Dessinioti C, Katsambas A. Seborrheic dermatitis: Etiology, risk factors, and treatments: Facts and controversies. Clinics in Dermatology.2013;31:34351.

21. Goldenberg G. Optimizing treatment approaches in seborrheic dermatitis. The Journal of Clinical_Aesthetic Dermatology. 2013;6(2):44-9.

22. Pradono J, Hapsari D, Sari P. Kualitas hidup penduduk Indonesia menurut international classification of functioning, disability and health (ICF) dan faktor-faktor yang mempengaruhinya (Analisis lanjut data RISKESDAS 2007). 2009. Bul. Penelit. Kesehat., Suppl:1-10.

23. Peyri J, Lleonart M. The Spanish group of the SEBDERM study. clinical and therapeutic profile and quality of life of patients with seborrheic dermatitis. Actas Dermosifiliogr. 2007;98:476-82.

24. Szepietowski JC, Reich A, Szepietowska EW, Baran E. Quality of life in patients suffering from seborrheic dermatitis: Influence of age, gender and education level. Journal compilation Blackwell Publishing Ltd. 2008; 52:357-63. 